\title{
SKOKIE, THE ACLU AND THE ENDURANCE OF DEMOCRATIC THEORY
}

\author{
Irving LouIS HoROWITZ* \\ Victoria CurTis Bramson $\dagger$
}

Not since the 1963 civil rights marches in Selma, Alabama, has a small city achieved such a high level of notoriety as Skokie, Illinois, where the American Nazi party proposed to hold a march some time in 1977. The circumstances surrounding each march can be said to illustrate the moral range of responses to the use of the march as a means of expressing political preference. Those who assert that civil rights and constitutional safeguards to free speech are inalienable quite properly note that it is easy to defend protest movements that have a broad constituency and an even wider popular base. It is another matter to defend the civil rights of a miniscule group of fascists lacking both a noble cause and popular support. Hence, it may be Skokie, not Selma, which turns out to be the touchstone of our faith in constitutional government. Let us not dwell on historical comparisons, but get directly to the heart of the legal and moral problems posed by l'affaire Skokie.

Writing in The Christian Century, Jean Caffey Lyles, has feelingly and properly put the Skokie issue in a fitting, paradoxical framework.

Even before any march has taken place, Skokie has become a symbol. It is now one of those American place names that evokes an event. We need to be reminded how deeply and indelibly the horrors of Nazi Germany are burned into the consciousness and memories of Jewish people, how vulnerable they feel to the possibility of "another Holocaust." Skokie has done that. We need also to be reminded how fragile and tenuous our commitment is to the First Amendment guarantees of free speech and assembly, when we are dealing not with bloodless abstractions but with the flesh-and-blood case of an obnoxious individual's or group's right to express ideals totally offensive to all the decent folk in our communities. Skokie is a disturbing symbol to remind us that the shallowness of our commitment to those principles could ultimately jeopardize the rights of all of us. ${ }^{1}$

The problem is: How do we resolve this paradox in such a way that does violence neither to constitutional guarantees of the American Nazi party nor to the human rights of a victimized people. That is the burden of this paper.

\footnotetext{
* Hannah Arendt professor of sociology and political science at Rutgers University and editorin-chief, Transaction/SociktY.

$\dagger$ Deputy Attorney General. Division of Criminal Justice. New Jersey Dept. of Law and Public Safety,

1. Lyles, Skokie as Symbol, 95 Christian Century 412 (1978).
} 
Skokie is a Chicago suburb. The community has a population of roughly 70,000 people. Slightly more than 40,000 residents are Jewish, and of these, 7,000 were World War II inmates of Nazi concentration camps. ${ }^{2}$ Frank Collin, ${ }^{3}$ leader of a small band of Nazi followers, decided to hold a march in this special setting. The community response was swift. The mayor of Skokie invoked three local ordinances: (1) requiring that demonstrators advance insurance against potential physical damages, set at $\$ 350,000 ;{ }^{*}$ (2) permitting the town council of Skokie to prohibit any speech or demonstration by members of political parties wearing "military-style" uniforms;" and (3) preventing the public display of the swastika as a symbol that intentionally promotes and incites hatred against persons by reason of their race, national origin or religion. ${ }^{6}$

Skokie authorities contended that the activities planned by the Nazi party were so offensive to its residents that they would become violent and disrupt the Nazi assembly, initially planned to take place on the steps of city hall on May 1, 1977. Therefore, they sought an injunction against any assembly at which military-style uniforms, swastikas or Nazi literature were present. Frank Collin appealed to the American Civil Liberties Union (ACLU) to represent the marchers' right to free speech and assemblage. The President of the Chicago ACLU chapter said: "We have no choice but to take the case." In its brief, ACLU attorneys claimed that so long as the demonstrators were peaceable, no injunction could be issued against their activities; furthermore, that such an injunction would constitute a prior restraint forbidden by the First Amendment. The ACLU relied upon First Amendment doctrines articulated consistently over the past fifty years by the Supreme Court, and recently by Chief Justice Warren Burger, who said: "The thread running through all of these cases is that prior restraints on speech and publication are the most serious and the least tolerable infringement on First Amendment rights."

After a hearing by the town council, an injunction by the village of Skokie was sought and issued. An appeal was taken. The response of the Illinois courts did not satisfy the ACLU, so an emergency appeal was taken to the

2. Village of Skokie : National Socialist Party of America, 69 Ill.2d 605, 373 N.E.2d 21, 22 (1978).

3. N.Y. Times, Jan. 12, 1980 at 7, col. 6, reported that Frank Collin was expelled from the American Nazi Party for illicit intercourse with minors and the use of Nazi headquarters in Chicago for purposes of sodomy with children. The report indicates that the Nazis "tipped" the police who arrested Collin.

4. Village Ordinance No. $77-5-N-994$ requires permit applicants to obtain $\$ 300,000$ in liability insurance and $\$ 50,000$ in property damage insurance.

5. Village Ordinance No. 77-5-N-996.

6. Village Ordinance No. 77-5-N-995, § 28-43.2.

7. Hamlin, Swastikas and Survivors: Inside the Skokie-Nazi Free Speech Case. ThE Crv. LiB., Rev. (March/April 1978), at 8, 22.

8. Nebraska Press Assn. v. Stuart. 427 U.S. 539, 559 (1976). 
U.S. Supreme Court, which ordered the Illinois courts to expedite a ruling or grant a stay of the injunction. ${ }^{9}$ A short time thereafter, the Illinois Appellate Court reversed portions of the injunction pertaining to the uniforms and literature, but affirmed the injunction as to exhibition of the swastika. ${ }^{10}$ It did so in part by invoking the "fighting words" doctrine that excludes from First Amendment protection words which "by their very utterance inflict injury or tend to incite an immediate breach of the peace."11 (This doctrine was utilized by the U.S. Supreme Court as recently as 1973. ${ }^{12}$ ) The Illinois Court held that the swastika was so offensive that its display could be enjoined anywhere in Skokie.

The ACLU immediately appealed to the Illinois Supreme Court. In its view, this use of the fighting words doctrine sets a very dangerous precedent. The ACLU claimed that such a doctrine could be extended easily to blacks marching in hostile white communities or to others with unpopular ideas who choose to assemble in areas where there are deeply antagonistic listeners. Thus, it was argued, the black power symbol of the clenched fist could have been prohibited in Selma when these communities were racially tense. On Janury 27, 1978, the Illinois Supreme Court upheld the ACLU position, including the right of Nazis to wear swastika armbands. ${ }^{13}$

Shortly after the Illinois Supreme Court rendered that opinion, the ordinances were ruled unconstitutional by the federal district court for the Northern District of Illinois. ${ }^{14}$ The court of appeals affirmed, with one judge dissenting in part. ${ }^{15}$ Certiorari was denied with Justice Blackmun, with whom Justice White joined, dissenting. ${ }^{16}$ The Illinois Supreme Court's ruling was that the American Nazi party can display swastikas, since its showing "is symbolic political speech intended to convey to the public the beliefs of those who display it." ${ }^{17}$ In substance, the court allowed the Collin group to march through Skokie as originally planned. A permit was issued to the Nazis for a demonstration on June 25, 1978. The Nazis, however, shifted their assembly to Chicago, where the demonstrations occurred without serious incident on June 24 and July 9, 1978. The issue raised by the Skokie controversy is not, however, moot. For, as noted by Justice Blackmun in his dissent from the Court's denial of certiorari in this case,

\footnotetext{
9. National Socialist Party v. Skokie, 432 U.S. 43 (1977)

10. Village of Skokie v. National Socialist Party of America. 51 Ill. App.3d 279, 293. 366 N.E.2d 347, 357 (1977).

11. Chaplinsky v. New Hampshire, 315 U.S. 568, 572 (1942). See also Cohen v. California, 403 U.S. 15, 20 (1971).

12. Norwell v. Cincinnati, 414 U.S. 14 (1973). But see Terminiello v, City of Chicago, 337 U.S. 934 (1949).

13. 69 III. 2 d at 619,373 N.E. $2 d$ at 26

14. 447 F. Supp. 676 (N.D. Ill. 1978).

15. 578 F.2d 1197 (7th Cir. 1978).

16. Smith v. Collin, 439 U.S. 916 (1978).

17. 69 Ill.2d at 615,373 N.E. $2 d$ at 24 .
} 
when citizens assert, not casually but with deep conviction, that the proposed demonstration is scheduled at a place and in a manner that is taunting and overwhelmingly offensive to the citizens of that place, that assertion, uncomfortable though it may be for judges, deserves to be examined. It just might fall into the same category as one's "right" to cry "fire" in a crowded theater, for "the character of every act depends upon the circumstances in which it is done." 18

The board of directors of the ACLU national office have fully supported the position of the Illinois chapter, including its apparent decision to coach the American Nazi party on proper responses. For example, the main thrust has been to equate the White Power slogan with the Black Power slogan, at least in terms of legal standing, and to avoid any mention of the social and historical antecedents of national socialism. This is clearly the implication of the position taken by David Goldberger, the Legal Director of the Illinois ACLU, who argues that defending unpopular causes is always ethically mandated and serves to renew the legal system and the Bill of Rights. ${ }^{19}$

The ACLU, as a result of its support of Nazi rights, has suffered angry criticism and close to 25 percent withdrawal. David Goldberger noted that "nearly 2,000 of the 8,000 members of the Illinois ACLU have resigned in the year following Skokie." ${ }^{0}$ The Anti-Defamation League of B'nai B'rith has argued that free speech could be restrained in this case because of the "psychic trauma" 21 that would result if the Nazis marched and displayed their swastikas. Various branches of the ACLU, like those in St. Louis, Houston and Jackson (Mississippi) voted not to aid the American Nazi party, although it did so in one instance because of the direct inflammatory appeal of a $\$ 5,000$ bounty "for every non-white person arrested or convicted for an attack on a white person." 22 Clearly, in this instance, Jews were classified with the nonwhite population.

The ACLU position is based on First Amendment guarantees of unimpeded free speech for all Americans. The ACLU was careful to distinguish between support for free speech and support for the ideology of the National Socialist Party of America. Rather than push this distinction, or for that matter obliterate it as a mere legal artifact, it might be worthwhile first to outline the legal precedents; second, the extra-legal implication; and third, the issues raised by Skokie.

The discussions between Abba P. Lerner and Aryeh Neier in the editorial pages of The New York Times ${ }^{23}$ have presented the issue of Nazis marching in

18. 439 U.S. at 919, quoting Schenck v. United States, 249 U.S. 47.52 (1919).

19. D. Goldberger, Would You Defend an Unpopular Cause: On Defending Nazis, 5 Barrister I (Winter 1977), at 47 [hereinafter cited as D. Goldberger].

20. D. Goldberger. supra note 18.

21. 578 F.2d at 1205-06.

22. D. Goldberger, supra note 18.

23. New York Times, Mar. 20. 1978, at A20. col. 3; id., Mar. 27, 1978, at A18, col. 5. 
Skokie as a conflict between two absolute principles: (1) the maintenance of a democratic order against its avowed enemies and (2) the maintenance of freedom of speech for everyone by resisting an incursion on the right to speak. We pose a third alternative: Is it not possible to distinguish instances in which free speech has no discernible and authentic political end, but only the end of public disorder and riots? And hence, should we not, in these instances, invoke an operational guideline such as Oliver Wendell Holmes' injunction against falsely shouting "fire" in a crowded theatre? ${ }^{24}$ Without wishing to stretch the analogy, can a strong case be made by the township, that Skokie, with its large Jewish population, is a theatre, in which a small band of selfdeclared Nazis, in effect, sought to incite a riot rather than hold a peaceful march, and hence to induce the same sort of panic and potential physical harm in the population that would occur if one cried "fire" in a crowded theatre? Arguments over strategems elevated to a level of principles have grave organization risks; but more, the Constitution is once again "on trial," to use the old cliché, and hence must be addressed directly and carefully.

II

An important legal issue raised by Skokie is not the right to speak freely, but rather, the obligation to hear what is spoken; especially if there is a consensus that the exercise of speech has no authentic political ends. Some guidelines on this problem are provided by the Vinson Court in the case of Feiner $v$. New York. ${ }^{25}$ This was an instance in which the speaker was inciting a crowd against himself by his speech. The police arrested the speaker on a charge of disorderly conduct. In affirming Feiner's conviction, the Supreme Court stated:

It is one thing to say that the police cannot be used as an instrument for the suppression of unpopular views, and another to say that, when as here, the speaker passes the bounds of argument or persuasion and undertakes incitement to riot, they are powerless to prevent a breach of the peace. ${ }^{26}$

The Feiner Court cited an earlier decision ${ }^{27}$ in which it was pointed out: "When clear and present danger of riot, disorder, interference with traffic upon the public streets, or other immediate threat to public safety, peace, or order appears, the power of the State to prevent or punish is obvious." 28 This statement was coupled with the observation that: "Equally obvious is it that a State may not unduly suppress free communication of views, religious or other, under the guise of conserving desirable conditions." ${ }^{29}$ Indeed the Jeho-

24. Schenck v. United States, 249 U.S. 47, 52 (1919).

25. 340 U.S. 315 (1951).

26. Id. at 321 .

27. Cantwell v. Connecticut, 310 U.S. 296 (1940).

28. Id. at 308 .

29. Id. 
vah's Witness Cantwell, although playing a phonograph record which attacked the Catholic Church in an area which was about 90 percent Catholic, was held not to have presented such a clear and present menace to public peace and order as to render him liable to conviction. The Supreme Court has, citing Feiner, reversed convictions for breach of the peace where there is no indication that any member of the audience threatened violence. ${ }^{30}$ Furthermore, a proper balance of the public interest with the free expression of ideas is required where, as here, the Nazis' planned activity is not "pure speech." 31

A distinction exists between the Skokie case and the preceding Supreme Court decisions in that the Supreme Court in each case was dealing with a criminal conviction (such as disorderly conduct) for persons who had already made their speeches. In the Skokie situation, officials were attempting to halt or regulate the assembly before it occurred, and hence faced the additional burden of justifying their regulation against the charge that it would be a "prior restraint" on free speech. However, as recently as 1976, the Supreme Court reaffirmed "that the guarantees of freedom of expression are not an absolute prohibition under all circumstances" 32 and that in some situations, prior restraints on speech may be justifed, although a great presumption against the use of prior restraints continues intact. It is of some consequence that the Court, while speaking of prior restraints in terms of both speech generally, as well as publication, emphasized the special need for an unfettered press to serve citizens in carrying out the exercise of their governing function in a democracy.

The concurrence cites Near $v$. Minnesota ${ }^{33}$ in which three possible exceptional circumstances justifying prior restraints on speech are delimited. These three exceptions to the prohibition against prior restraints are: (1) obscene publications; (2) incitements to acts of violence which threaten the security of community life; and (3) speech meriting constitutional protection which nevertheless may be suppressed prior to publication in the interest of some overriding countervailing interest. ${ }^{34}$ Although Justice Brennan notes that the third category has only been mentioned in passing, he acknowledges that the first two categories have been interpreted as situations in which the "speech involved" is not encompassed within the meaning of the First Amendment. ${ }^{35}$

The idea that some types of speech (notably obscenity, libel and "fighting

30. Cox v. Louisiana, 379 U.S. 536.551 (1965): Edwards v. South Carolina, 372 U.S. 229. 236 (1963), rey'g State v. Edwards, 239 S.C. 339, 123 S.E.2d 247 (1961). But see 'Terminiello v. City of Chicago, 337 U.S. 1 (1949) where, with four Justices dissenting, the Court reversed petitioner's conviction despite evidence that a riot was caused by his speech, because the statute under which he was convicted was overly broad.

31. 379 U.S. at $\mathbf{5 5 5}$.

32. 427 U.S. at 570 .

33. 283 U.S. 697.716 (193I).

34. 427 U.S. at 590.

35. Id. 
words") are unprotected by the First Amendment has been well stated by Alexander Meiklejohn ${ }^{36}$ who divides speech into two classes depending upon its function in a democracy. As self-governors, people have a need to hear or be informed which is absolute but an individual's need to speak is subject to reasonable due process limitations, like any other private right. If private speech such as libel, which has long been recognized as subject to reasonable regulation or abridgment, is lumped together under the First Amendment with speech which is necessary to the governing function, Meiklejohn warns, it will follow that this freedom of speech in the public interest may also be abridged. This unnecessary lumping together seems to be precisely the error of the ACLU. While protecting the Nazis, as a political movement devoted to "White Power," in their expression of ideas, the ACLU has come to view the swastika, accepted by the Skokie audience as a symbol of genocide, as deserving of constitutional protection. In so doing, the ACLU has gone far beyond their ethically acclaimed purpose of protecting a political minority and thereby demeaned both its own function and that of the First Amendment. ${ }^{37}$

The swastika must be viewed both historically and in consideration of the choice of audience for its display. To choose an audience such as the Skokie community belies the Nazis' march as part of the exposition of ideas and reveals the Nazi purpose to deliberately provoke violence. A discernment must be made between speech with authentic political ends and speech that has public disorder and riots an an intended consequence. Indeed, the Illinois Appellate Court's invocation of the doctrine of "fighting words" seems precisely on point in relation to display of the swastika in Skokie. As was pointed out in Chaplinsky v. New Hampshire:

It has been well observed that such utterances (fighting or insulting words)
are no essential part of any exposition of ideas, and are of such slight social
value as a step to truth that any benefit that may be derived from them is
clearly outweighed by the social interest in order and morality.

This debate goes directly to the root of the 1919 decision in Schenk $v$. United States. ${ }^{39}$ In that decision, Justice Holmes invoked the now famous analogy that falsely shouting "fire" in a theatre is akin to creating a clear and present danger to life and limb. What appeared to be a transparent solution only deepened a constitutional ambiguity. We have to keep in mind that Justice Holmes was handling a political hot potato. The legal argument under review pertained to the printing and circulation of documents obstructing recruitment and enlisting services to the U.S. armed forces when the nation was at war. The Schenk defense was based on freedom of the press. The exact

36. A. Meiklejohn, Political Freedom 79-80 (1960). [Hereinafter cited as A. Meiki.fjohn].

37. Statement of the American Civil Liberties Union, before Subcommittee No. 4 of the House Judiciary Committee, on H.R. 13315. April 26, 1972.

38. 315 U.S. at 572.

39. 249 U.S. 47. 
wording of the Holmes' position, so central to the Skokie situation, is as follows:

The character of every act depends upon the circumstances in which it is done. ... The most stringent protection of free speech would not protect a man in falsely shouting fire in a theatre and causing a panic. . . The question in every case is whether the words used are used in such circumstances and are of such a nature as to create a clear and present danger that they will bring about the substantive evils that Congress has a right to prevent. It is a question of proximity and degree. ${ }^{40}$

It has been argued that Holmes' analogy was not quite appropriate to the particular issue at hand; any more than it would have been in preventing recruitment during the Vietnam War when the public sentiment was far more divided on the moral purpose of the military recruitment. In a town such as Skokie, which can be viewed as a theatre, Holmes' argument would seem to be impregnable. Since the opinion affects persons that directly molest or threaten third parties, or innocent victims as the case may prove, it is not dependent on how one feels about American foreign policy in general or in relation to a particular war.

Holmes' clear and present danger test was not, as some ACLU lawyers hold, a formula for preventing the exercise of free speech, but rather a pragmatic test intended to invalidate a conservative Court's knee-jerk rulings against radicals. ${ }^{41}$ The clear and present danger test was a compromise formula that enabled Holmes to enlist the authority of a unanimous Supreme Court in Schenk for this open-ended standard. When the Court sought to extend the use of the clear and present danger standard to suppress the distribution of left wing literature, as in the case of Gitlow v. New York, ${ }^{42}$ Holmes entered a powerful dissent that has become a benchmark against the freewheeling use of the clear and present danger test. The Holmes dissent held that such a view, equating political argument with the creation of revolution and threat to government itself, and thereby justifying the suppression of political argument, profoundly misstated the original intent of the clear and present danger doctrine. He drew a sharp line between an idiosyncratic intention to riot for the purpose of causing destruction and a politically related intention to make a revolution for the purpose of causing social change.

Every idea is an incitement. It offers itself for belief, and if it is believed, it is acted on unless some other belief outweighs it, or some failure of energy stitles the movement at its birth. The only difference between the expression of an opinion and an incitement in the narrower sense is the speaker's enthusiasm for the result. ${ }^{43}$

40. Id. at 52 .

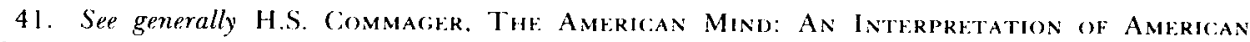

Thoucint and Chakactier Since. Thr 1880's, at $381-90$ (1950).

42. 268 U.S. 652 (1925).

43. Id. at 673 (Holmes, J., dissenting). 
What had to be determined in the proposed Skokie march is whether it represented any discernible attempt to convince the public or to alter their opinions. Certainly, in terms of the immediate, proximate public the Nazi effort would seem to fall outside the range of protected speech under Holmes' now accepted Gitlow dissent.

The purpose of the Nazi march through Skokie requires both legal and political elaboration. If indeed, a claim was made that this constitutes only one step in a long march toward social revolution (or counter-revolution), protection under the First Amendment would be an entitlement. It is apparent to all parties to this dispute that the purpose of the march is to incite civil disorder and political disarray. ${ }^{44}$ The distinction between legitimate political aims and illegitimate organized mayhem distinguishes the march from the symbol. In this sense, the march may be viewed as a rallying cry for "White Power," but the symbol taken as speech by itself is clearly far beyond such a modest and legitimate organizing premise. If the Nazi march is political, whether it represents the start of a revolution or not, it cannot be prohibited under the First Amendment because of any presumed eventual threat to the established government. However, the swastika as symbolic speech taken by itself represents just the sort of instigation to violence which is outside the protection of the First Amendment.

Brandenburg $v$. Ohio ${ }^{45}$ involved a Ku Klux Klan leader speaking on television who was convicted of violating a statute which prohibited "advocat[ing] . . . crime, sabotage, violence, or unlawful methods of terrorism as a means of accomplishing ... political reform." 46 In that case, it was held that one cannot punish mere advocacy. But the Court noted in Brandenburg that the proscription even against punishing advocacy is not applicable to a situation where "such advocacy is directed to inciting or producing imminent lawless action and is likely to incite or produce such action." 47

Justices Black and Douglas, in concurring opinions in Brandenburg, argued that the clear and present danger doctrine should have no place in the inter-

44. As Justice Jackson observed in his dissent in Terminiello,

We need not resort to speculation as to the purposes for which these tactics are calculated nor as to their consequences. Recent European history demonstrates both. Hitler summed up the strategy of the mass demonstration as used by both fascism and communism: "We should not work in secret conventicles but in mightly mass demonstrations. and it is not by dagger and poison or pistol that the road can be cleared for the movement but by the conquest of the streets. We must teach the Marxists that the future master of the streets is National Socialism, just as it will some day be the master of the state.' .. First laughed at as an extravagant figure of speech, the battle for the streets became a tragic reality when an organized Sturmabterlung began to give practical effect to its slogan that 'possession of the streets is the key $t o$ power in the state'. 337 U.S. at $23-24$ [citations in the original omitted].

45. 395 U.S. 444 (1969).

46. Id. at 444-45.

47. Id. at 447 . 
pretation of the First Amendment. Justice Douglas' amplification is interesting:

The example usually given by those who would punish speech is the case of one who falsely shouts ["]fire["] in a crowded theatre. This is, however, a classic case where speech is brigaded with action. . . They are indeed inseparable and a prosecution can be launched for the overt acts actually caused. ${ }^{48}$

In this instance, Douglas argued that the law prosecutes transgressions, not presumptions of transgression through incitement; that a proper remedy is available through criminal enforcement for any action upon the speaker's advocacy of violence. He noted that the clear and present danger test had been applied to threats which, although often loud, were made serious only by "judges so wedded to the status quo that critical analysis made them nervous." ${ }^{49}$ In part, the Skokie case reflects just this consideration of the line between ideas and overt acts. Basically, the position of the Jewish community is that riot and disorder will inevitably result from symbolic provocation, whereas the position of the ACLU is that such riots and disorders cannot be anticipated but they are prosecutable when they occur. Again, this raises a classic problem not only in law, but in public policy.

In Edwards $v$. South Carolina, ${ }^{50}$ the defense noted that there was no evidence that onlookers were anything but curious. That is to say, they were not hostile and nobody in the crowd would threaten or desired to threaten. Hence, the marchers were threatened only by those who presumably were upholding the law, not the public. In this instance, South Carolina held for the marchers. One might argue that the difference between Selma and Skokie is precisely the attitudes of the onlookers and, therefore, what the community actually desired in the case of Selma was far more ambiguous than in the case of Skokie. Still, it might be asked whether if the South Carolina crowd was uniformly opposed to the beliefs and persuasions of the civil rights marchers they would be entitled to the same protection that the Skokie community insisted upon with respect to an incitement to riot. At this point, we move beyond the confines of law into the question of public morality: namely, the egalitarian concerns of the civil rights marchers and the antithetical antiegalitarianism of the national socialist marchers. Hence, what a society is protecting is not exclusively its legal precedents, but its community order.

The argument against applying the Holmes position to Skokie has been stated by Carl Cohen, who cites three reasons why the analogy between a theatre and Skokie is seriously flawed.

First, the theatre audience is captive, subjected against its will to the shout and its sequel. Not so for any gathering for a Nazi parade or demonstration.

48. Id. at 456-57 (Douglas, J., concurring).

49. Id. at 454 (Douglas. J., concurring).

50. 372 U.S. at 229. 
Those angered or offended are free to stay away, or to leave; they need have nothing to do with the affair. The panic in the theatre traps and injures those present for reasons entirely unrelated to the shout: that false alarm is not essentially speech at all; it is no different from the fraudulent ringing of an alarm bell. Of the audience any Nazi march may draw, all this simply cannot be said. Second, the shouted warning is of such a nature that it permits no discussion. It is not the expression of an opinion but a signal for flight, giving no opportunity for reasoned reply. The Nazi demonstration may be answered with counter-demonstrations; it may be refuted, in print or by voice; then or later. Nazi demonstrators offer no threat of immediate calamity comparable to that of a false alarm in a crowded hall. Third, the alarm in theatre, is, by hypothesis, false; we would think very differently of an honest warning. Nazi views are also false, no doubt, but being right is not a condition on which permission to demonstrate may be premised. Who should have that permission if it were? And who decides? 51

Those angered by the Skokie march cannot really stay away or leave. To stay away would mean to abandon the town to the Nazis, and to leave, is to run the risk that residents would never get back to their homes. To make a situation ripe for a classic putsch is surely not a solution the First Amendment supports. Cohen makes a bland assumption that no threat exists to the Skokie residents. Implicit is the belief that the imbalance in the size of the contending forces would prevent any immediate threat from occurring. But in fact, the coup is ingrained in Nazi ideology; $;^{52}$ the existence of mass support simply is not premised. Cohen himself indicates the danger of his point by arguing that rational judgment upon any position "requires that it be heard." But in fact, what is required is a right to speak, and a proper forum for the exercise of free speech. There is no constitutional requirement to listen. This might be prudential on intellectual grounds, but it is scarcely a serious argument for permitting the march. The freedom of speech guaranteed by the First Amendment would not necessarily dictate the result reached by the Illinois Supreme Court. The protection afforded speech in the past has not precluded regulation of conduct associated with speech or regulation of the place in which the speech may occur.

The concept of community privacy cannot be easily dismissed. The rights of the Skokie villagers represent a special case of what Edward J. Bloustein ${ }^{53}$ has properly defined as an invasion of group privacy; the right of people to "huddle" without fear of outside interference and, hence, a perfect counter-

51. Cohen, Skokie-The Extreme Test, 226 Nation 423 (1978)

52. Goebbels expressed this when he said:

When democracy granted democratic methods for us in times of opposition, this [Nazi seizure of power] was bound to happen in a democratic system. However, we National Sociatlists never asserted that we represented a democratic point of view, but we have declared openly that we used democratic methods only in order to gain the power and that, after assuming the power, we would deny to our adversaries without any consideration the means which were granted to us in times of [our] opposition.

1 Nazi Conspiracy and Aggression (GPO 1946) 202, Docs. 2500-PS, 2412 PS.

53. E. Bloustein, Individual and Group Privacy 125 (1978). 
part to individual privacy or liberty, namely, the integrity of the social structure. To view privacy as a purely individualist phenomenon and to disregard the social nature of privacy is a threat to any possibility of social cohesion. It is precisely this risk of public disorder that the Nazi swastika represents. Group confidences are real; collective propriety rights deserve to be taken seriously. Of course, one might respond by saying that Skokie is too big and amorphous to be viewed as a cohesive group. In fact, the exact stipulation of such group privacy becomes a central empirical factor. However, to introduce this notion of the group into the discussion over Skokie at least permits a realistic assessment of the limits of democratic endurance from totalitarian threats.

In United States $v$. O'Brien, ${ }^{54}$ Chief Justice Earl Warren delivered the opinion for the Court, which found a statute prohibiting the burning of draft cards to be constitutional. O'Brien burned his draft card publicly and argued that his act was protected "symbolic speech" within the First Amendment since his purpose was a communication of his anti-war ideas in an effort to encourage others to re-evaluate their positions with Selective Service and the armed forces. The Court noted that:

We cannot accept the view that an apparently limitless variety of conduct can be labelled "speech" whenever the person engaging in the conduct intends thereby to express an idea. . . This court has held that when "speech" and "nonspeech" elements are combined in the same course of conduct, a sufficiently important government interest in regulating the nonspeech element can justify incidental limitations on First Amendment freedoms. ${ }^{55}$

In another decision dealing with symbolic speech, ${ }^{56}$ Justice Fortas held for the Court that suspending high school students for wearing black armbands to school to publicize their objection to the Vietnam War violated the students' First Amendment right to freedom of expression, including such "symbolic speech." It was determinative in the Court's opinion that evidence in the record did not indicate "that the school authorities had reason to anticipate that the wearing of the armbands would substantially interfere with the work of the school or impinge upon the rights of other students." 57 Justice Black dissented on the ground that a public school was not a proper forum for such speech whether "symbolic" or "pure." He noted that he "never believed that any person has a right to give speeches or engage in demonstrations where he pleases and when he pleases." 58

Every case involving the clear and present danger doctrine hinges on a fine distinction. Thus, even a First Amendment absolutist such as Black makes provision for regulating the time and place for protests. Not to do so is to in-

\footnotetext{
54. 391 U.S. 367 (1968).

55. Id. at 376 .

56. Tinker v. Des Moines Independent School District, 393 U.S. 503 (1969).

57. Id. at 509 .

58. Id. at 517 (Black, J., dissenting).
} 
vite social chaos rather than social change. One might well claim that such a situation arose with respect to Skokie.

\section{III}

Alexander Meiklejohn points out that under the Bill of Rights there are two types of liberties of speech. "There is a freedom of speech which the First Amendment declares to be nonabridgeable; but there is also a liberty of speech which the Fifth Amendment declares to be abridgeable."59 Meiklejohn goes on to declare that the distinction between the two is basic, "The Fifth Amendment it appears, has to do with a class of utterances concerning which the legislature may legitimately raise the question; shall they be endured? The First Amendment on the other hand, has to do with a class of utterances concerning which that question may never be legitimately raised." "Mo Meiklejohn further observes: "The First Amendment then is not the guardian of unregulated talkativeness . . . What is essential is not that everyone shall speak, but that everything worth saying should be said." 61

A distinction must be made between the Nazis' rights to march and to display the swastika. No clear and present danger could probably be shown to exist solely because a few Nazis will march through a small town proclaiming "White Power." The swastika, however, is such a well known symbol that its meaning cannot be reduced to a "White Power" slogan. It directly sanctions genocide $^{62}$ and it is the right to hear versus the right to speak. The right to hear under the First Amendment is completely and absolutely protected so that citizens may be properly informed to exercise self government. The right to speak falls under the Fifth Amendment's due process clause as to speech inessential to the governing function and hence, is much more limited and limiting.

Even within the Meiklejohn framework, one can call the march political, but not the swastika. The latter symbol is beyond politics; the distinction between politics and murder is emphasized by the choice of an audience. The selection of Skokie clearly exceeds concern for presenting the case for white Power and goes to the heart of Jewish and minority concerns. The Nazis claim that they are doing nothing more than protecting white minority concerns is belied by the special nature of the swastika as a symbol.

By carefully distinguishing between the rights of marchers and "showing the colors" as it were, a distinction is made between legitimate politics, which even Nazis can partake of, and incitement to terror, which oversteps the limits of the First Amendment. The right to murder or to libel is beyond the endur-

\footnotetext{
59. A. Meiklejohn, supra note 35 , at 36 .

60. Id.

61. Id. at 26.

62. I.L. Horowitz, Taking Lives: Genocide and State Power, at 29-30 (1979).
} 
ance of First Amendment support. The gap between reality and symbol thus becomes the cutting edge. Those who prevent the march by attacking the marchers can be prosecuted for criminal activities, while those who convert the march into a justification for genocide are subject to constitutional constraints.

It is evident that Nazi activities have already resulted in serious setbacks for those who believe change can be orderly as well as necessary. The ultraleft Progressive Labor Party, aimed with clubs and lead pipes, invaded the Chicago offices of the American Nazi party on April 8, 1977. The thirty masked attackers injured two Nazis. A female attacker was hospitalized in intensive care with head injuries. The confrontation was brief and no arrests were made. One day later, the Jewish Defense League issued an advertisement in The New York Times "ensuring further acts of Zionist Hoodlumism," including this item: "This small bunch of Zionist Hoodlums will stop the Nazi march in Skokie. ${ }^{63}$ It is not difficult to imagine the Progressive party and the Jewish Defense League coming to blows on that occasion since they are so far apart on almost all other political issues. In the Skokie case, we have a clear case of social disintegration. We must, therefore, return to the Tinker ruling to gain a better appreciation of the distinction between free speech and symbolic speech.

... [I]n our system, undifferentiated fear or apprehension of disturbance is not enough to overcome the right to freedom of expression. . . [H]azardous freedom-this kind of openness-that is the basis of our national strength . . . ... [F]or the State in the person of school officials to justify prohibition of a particular expression of opinion, it must be able to show that its action was caused by something more than a mere desire to avoid the discomfort and unpleasantness that always accompany an unpopular viewpoint. . . . . . [T]he record fails to yield evidence that the school authorities had reason to anticipate that the wearing of the armbands would substantially interfere with the work of the school or impinge upon the rights of other students. ${ }^{64}$

Tinker may restrict freedom of expression to prohibit symbolic speech; however, the determinative factor was that there was no evidence that school authorities had reason to anticipate that the wearing of black armbands to protest the Vietnam War would substantially interfere with work of the school or impinge upon the rights of other students. The wearing of the swastika is also what may be termed "symbolic speech." However, to so designate it means that the symbol is clearly understood to mean something which can be understood by merely viewing the symbol itself. We must look to the swastika, therefore, as a symbol of what? Its identification is with Nazi Germany, not as merely a fascist and racist movement of history, but as a regime that had as one of its primary goals the extermination of each and every Jewish person.

63. New York Times, Apr. 9, 1978, at E20, col. 1.

64. 393 U.S. at 508-09. 
Such a symbol would convey a threat of genocide, particularly to those persons who have experienced the horror of concentration camps, the horror of watching friends and family taken and murdered by a vast organization with all political power behind it. Such a symbol certainly does convey a particular meaning. The question is: Does an assembly have the right under the First Amendment to so blatantly advertise its desire for murder?

As a political point of view, any idea may be spoken under the Constitution, but does, or should, the Constitution protect a call to murder? The Illinois Appellate Court made an analogy to "fighting words," words which have no meaning other than to bring on physical retaliation. The Supreme Court has held, in interpreting the protection of the First Amendment, that certain language is not protected by the amendment.

Hardly anyone takes the Nazi party seriously as an immediate threat to national security. It has even been argued that it is better to have the Nazis march through Skokie as a political act than to drive them underground so that they can express their political position only through acts of terror. Indeed, this is probably the best reason for granting the Collin group permission to march. However, Nazi political symbols are such that a clear incitement to violence is undoubtedly intended. The purpose of choosing Skokie is self-evident: not to preach or convert new allies, but to incite reaction or invite panic. To speak of the Skokie march as "peaceful" is a contradiction in terms; similar to declaring that homicide is simply a device for conflict resolution.

The ideology represented by the Nazi movement includes obedience to authority, obligations to the state, and order in the world. It holds out scant prospects for the survival of dissent, disobedience, and for that matter, disorder in the face of tyranny. Aspects of the Nazi legacy, at least with respect to mass murder as a technique of rule, and symbols which stand for mass murder, such as the swastika, can legitimately be distinguished from the civil liberties of marchers. ${ }^{65}$ The notion that opponents of the Nazis can retaliate by wearing the Star of David simply advocates a war of symbols, not the tranquility of the social system. They are furthermore equating symbols, thereby cheapening the meaning of a world historic religion and culture in the process. Such a view fails to reckon with the private nature of religious and cultural beliefs and forgets that the forced wearing of the Star of David by ghetto Jews was a degradation imposed upon Jewish communities by the Nazis preceding their extermination. Hence, a war of armbands is not the solution, but very much part of the problem.

In Tinker, the lack of evidence of any intention of wrongdoing becomes critical. This is not the situation in Skokie. There may have been symbolic am-

65. H. Arendt, Eichmann in Jerusalem: A Report on the Banality of Evil, at 54-62 (1964); H. Arendt, The Origins of Totalitarianism, at 460-63 (1966). 
biguity regarding the black armband, but there is no parallel confusion as to the meaning of the swastika. The ACLU response seems to be that, whatever the symbol represents, it is permissible.

It is important to recognize that neither the absolutists nor the relativists are making a purely legal case. Both must perforce draw attention to the actual or implied threat by any march, or any symbol system. The question is: Where do we draw the line? It must be somewhere between the right of a society to maintain order and hence deny political rights to Nazis and the absolute right of the Nazis to march. Whatever their potential for destroying society, the goal must be to maintain maximum freedoms with minimal risk. One might immediately draw a parallel to Sidney Hook's ${ }^{66}$ distinction between dissent and treason. But in fact, the concerns of law are less linguistic and more substantive in nature. Law regulates the forms under which change occurs so that continuation of legal processes are feasible. To argue that law must sanction lawlessness, or that the right to free speech can be proven only be defending the rights of those who would suppress speech, is to place a burden on a legal code that is objectively implausible and logically self-contradictory.

We argue for a new precedent. A great deal hangs on a fine distinction because the concrete facts in this case are important. This is characteristic of most First Amendment cases. The position taken here, namely, to permit the Nazis to march through Skokie and to prohibit their exhibiting their symbols, may seem arbitrary. We think not. The Nazis are a unique political tradition due to their advocacy of and history of mass genocide; in the case of the United States, they advocate genocide against Jews and blacks. The general slogan of White Power can be asserted to fall within constitutional safeguards provided by the First Amendment, but the symbol of genocide, the swastika, is the direct link between Skokie and Auschwitz, between the invasion of a quiet Jewish town and the destruction of equally quiet European Jewish villages and neighborhoods by the hundreds in World War II.

The fine line of law thus broadens to embrace the broad swathe of history. Meiklejohn ${ }^{67}$ properly points out that if we protect evil under the rubric of the First Amendment, the entire amendment looks wrong. That is to say, if the amendment becomes a cover to protect obscenity, mayhem and murder, the original intent of the amendment is subverted. By making a fine distinction between marching and showing the swastika, we provide not just a legal nit-picking notion, but attempt to construct a limit that does not subvert the contents or the intents of a democratic society.

The fine distinction does not involve the silencing of a speaker, even a Nazi, hence it does not confront Feiner and its progeny. Speakers are not being silenced nor are they being imprisoned for their ideas. They are limited

66. See S. Hook, Heresy, Yes-Conspiracy, No, at 72 (1953).

67. A. MEIKLEjohn, supra note 35. 
solely from showing a symbol of death to people who were directly menaced by the swastika in the 1940s. Further, we are not advocating limits upon speech or parading, but arguing that free speech does not entail a necessity to hear. Villagers should not have to leave their town in order to avoid threats to their bodily and mental security. The appellate court's original rulings distinguishing political speech from symbols of death seems to be eminently sensible and deserved to be allowed to stand.

IV

One cannot ignore the internal history of the ACLU as an element in its pursuit of principles in the Skokie case. It is a history in which the ACLU leadership often compromised and temporized with agencies of the government in the prosecution of communists and other left-wingers and in which the notion of civil liberties was rationalized to such a degree that it threatened the organization itself being identified with a pernicious doctrine of the "vital center." The context of that inner history and recent revelations about this rather sordid period in ACLU history during the McCarthy era can help place the fanaticism of its present leadership on the Skokie affair in proper perspective. The ACLU leadership does not want to make the same mistakes; a portion of the membership. risks making the opposite mistake of treating Nazis as cranks who will go away if left alone. After all, the Munich putsch led to the Nazi system only a decade later. Within such a framework, the problem of the ACLU can be seen as a problem of us all: At what point are we willing to sacrifice the principle for the polity; individual autonomy for community order?

Aryeh Neier, Executive Director of the ACLU since 1970, clearly draws the parallel between Nazis and Communists.

In a way, the protests over the Skokie case involve the same fundamental issues as the contacts revealed in the FBI files. In both instances, despised clients are at issue-the Nazis today, Communists in the 1950s. The members resigning because of the ACLU defense of free speech for Nazis take the same approach. They, not the ACLU, their letters contend, are defending liberty. By not supporting free speech for Nazis, they see themselves combatting the Nazi cause. The Nazis, after all, would savagely repress civil liberties in the United States if they came to power, much as they did when they were in power in Europe. Sadly, I am forced to the conclusion that the ACLU staff members in the 1950s who fed information about their colleagues to the FBI persuaded themselves that they were defending the cause of liberty. With the advantage of hindsight, we can call what they were doing betrayal. Few in the ACLU now would disagree. But if we assert that failure to defend free speech for Nazis and the KKK today would be a betrayal, the chorus of disagreement is loud, vehement and passionate. The pressure to retreat from principle is as great today as in the 1950 s. It only wears a slightly different guise. ${ }^{68}$

68. A. Neier, Adhering to Principle: Lessons from the 1950's, THE Civ. LiB. Rev. (Nov/Dec 1977), at 26,32 [hereinafter cited as $A$. Neier]. 
The advantage of hindsight works in both directions. There is a metaphysical presupposition that Communists really were much better than they were made out to be by their adversaries, that ACLU members overreacted, that the Communist threat was a fiction. Indeed, this viewpoint has become part of the current political fashion. However, the American public knew relatively little of the Stalinist slaughterhouse in the early 1950s. There was no Gulag Archipelago to light the way; no Khruschev revelations of Stalin's abuses of power. Hindsight may also teach us that the American Communist party, under the Stalinist leadership of William Foster and Eugene Dennis was indeed part of a Soviet hegemonic thrust, and not a legitimate national party but an agent of a foreign power.

The ACLU position might well be that it was right before and right now. That is to say, that its reservations about all out support for the Communist party were correct, in that the party at that time represented a foreign power; and correct in its support of the Nazis because there is no corresponding major foreign power to whom this band of Nazis is beholden. There is little doubt that Communist party politics have changed dramatically over the years, and the ACLU attitude toward the communist issue reflects these changes. But whether the ferocity of Soviet expansionist politics between 1947 and 1952 was such as to invite uninhibited support by civil libertarians is questionable.

It should not be forgotten that the Nazi movement, like the communist movement, is international in character. True, German national socialism was crushed; and hence the heart and soul of Nazi movements overseas were paralyzed. To ignore the conspiratorial nature of Nazism, to isolate an event in Skokie from the history of Nazi persecution of minorities, may represent a sort of underreacting to the Nazi menace of today that is as dangerous as was overreacting to the communist menace of the fifties. In either case, hindsight is a poor guide to the labyrinthian issues raised by the Skokie case.

There are three main extralegal arguments that have been consistently invoked by ACLU advocates that seem prima facie strcng but on closer examination are spurious.

First is the media argument: making such a legal fuss over a small band of Bundists with flag but without country only glorifies their position. It magnifies what they are doing, gains them an inestimable amount of media publicity and press coverage, and, as a result, these hippies of the right gain an enormous benefit while liberals fall out among themselves. The fallacy in this line of reasoning is that every major judicial confrontation is limited in empirical scope but of immense potential political significance. The media response is not geared to the former but to the latter. Hence, to argue in favor of granting a marching permit simply on the grounds that it puts the event in perspective may be to badly misread what that perspective is.

Second is the ship-in-the-night argument: by granting a marching permit, 
this small group of Nazis will simply and silently wend their way through the parade route and that will be that. Again, the larger issue of the selection of a special Chicago Jewish suburb and the possibility that the same ritual may be performed in other such cities and contexts is left unexamined. Worse, an assumption is made that the Nazis will simply start and conclude their parade within the legal limits, but the contradiction here is that they are Nazis! They believe in the theory and practice of national socialism, and that includes the strategy and tactics of the putsch, or the police or paramilitary takeover of state power. Thus far, the absolutists on the side of the First Amendment have assumed that although Collin and his group are avowedly antidemocratic they will behave in a democratic fashion. This probably is true in the Skokie case, but would the same logic apply if the number of Nazis and the size of the city were different?

Third is the organizational argument: by focusing energies and ideas on the Skokie issue, the opponents to the national ACLU position are diverting energies and ideas from other aspects of its work. This undoubtedly is largely true. One point we are making is that an authentic form of democracy does not require 100 percent identification with any organization's set of premises and goals in order to provide continuing support. However, there are problems with this sort of logic. For one, the special meaning of Skokie may be of such overriding concern that defense or opposition to the march defines the precise nature of one's vision of civil liberties. And as a problem in political measurement, surely people have a right, even an obligation, to question their participation in the ACLU effort not on minimalist, but on maximalist, grounds. That is to say, the Skokie case is exactly what measures the ability to participate effectively in the ACLU. After all, when the ACLU tarried on the communist issue in the fifties and shamefully and by its own admission, underhandedly engaged in forms of collusion with FBI authorities at the highest levels, one did not hear that after all the organization was doing good work on most civil liberties questions, even though they were temporizing on the communist issue. Indeed, the formation of the Emergency Civil Liberties Union in that period indicates how little weight such an argument should be given, even if it does come from the ACLU executive director.

A serious problem in the Skokie affair is the role of the ACLU as an intervenor and not just a provider of legal talent. Throughout, the American Nazi party has been coached by ACLU attorneys to avoid inflammatory language, to say nothing of the Third Reich, to avoid praise of Hitler or damning of Jews and blacks. Instead, it has announced as the theme of Skokie: "free speech for the white man." The ACLU then can claim that White Power may lack the virtues of Black Power, but from a constitutional viewpoint, one cannot deny to advocates of the former what the courts have previously granted to the latter. One can scarcely imagine a more cynical abuse of legal 
services, services which involve, beyond coaching, ideological laundering, so that the Nazis for public relations purposes are purged of their fundamental beliefs in the racial inferiority of blacks and of Jews and their advocacy of genocide.

By constantly raising false and inappropriate analogies between Skokie and Selma, between the White Power and Black Power movements, the ACLU has made equations which discredit the civil rights movement. Within the broad tradition of pragmatic jurisprudence, the purpose of a movement in not mentioning its prior history, must have a bearing on the legal evaluative processes. The swastika is not an abstract symbol of an indeterminate variety; it represents massacre. In a western cultural context, it is the archetypical symbol of genocide in our times. It cannot be laundered to mean simple advocacy of White Power. The ACLU formulas serve only to divide Jews from their natural allies in such matters, blacks and young radicals. The ACLU has placed the Jewish community in the position of advocating order at the expense of law. Nothing could be more insidious and erroneous. It is of no small consequence that the ACLU intended to push the Skokie matter to the Supreme Court and would likely have had an isolating effect on the Jewish community as a whole. The ACLU worries about its membership, but seems not to worry about its contributions to ethnic and racial polarization.

Some of the defense of the Nazi march moves far beyond standard ACLU agitprop. Nat Hentoff claims that for a court to limit freedom of expression on the grounds that 'violent reaction' will otherwise result is to impose on the First Amendment a 'heckler's veto.' And that doctrine, if emulated elsewhere, could shut off all kinds of speech, actual and symbolic." 69 This is probably the most bizarre twist yet. The Nazi march, intended to heckle and incite the local Skokie inhabitants is by a magic sleight of pen transformed into the victim. The Skokie denizens become the hecklers. Indeed, Hentoff, in familiar overkill, says that the Illinois court "balances the First Amendment against mob rule, and the latter wins."70 The victims become the mob.

It is clear that the problem presented by Skokie, both for the "libertarians" who believe in civil liberties without restraint, and those who might be called "communitarians," who believe in social order, and hence relatively high amounts of restraint, are not entirely resolved by appeals to the law. Still, in American legal history, there does seem to be a constitutional sentiment which makes fairly powerful distinctions according to the purpose of political behavior. In this sense, the pragmatic guidelines of the clear and present danger thesis offers a valuable paradigm for action, or inaction as the case may be. If there is a common view that the Nazi marchers have chosen Skokie not so

69. N. Hentoff, ACLU's Trial by Swastika, Soc. PoL'Y, Jan. 1978, at 51.

70. Id. 
much as a theatre of ideas, but as a dramaturgy of troubles, then the kind of opposition received by the ACLU to its stand is at least understandable, if not entirely defensible. It would seem terribly naive of its leadership to argue that the Skokie matter impedes much of its other activities, since Skokie is the centerpiece issue of constitutional law at this time.

There is a terrible danger in throwing out the baby, in this case the ACLU, with the bathwater, a small band of Nazis of no immediate consequence. The purpose of the ACLU is not simply to perform the role of legal agency for the interpretation of constitutional law, but rather to serve as a pressure group with maximum vision of free speech and minimum acceptance of any curbs on that right. The reasons for its existence are rooted in abuses of free speech throughout American history. Hence, to deny its support on the basis of one issue or one instance is to ignore the nature of interest-group politics and to expect the ACLU to behave as a supreme court might. This is the hub of the problem. The ACLU is not a law-making agency. It is an interest-group political apparatus and deserves every support on those terms, whether or not there is agreement or disagreement on its attitudes toward the Skokie case. On the other hand, the ACLU authorities must stop behaving as if any opposition to its position is divisive and erroneous on the face of things. Skokie is not one of many ACLU activities; in the current period, it expresses the will of its leadership over and against the sensibilities of its membership.

The issue may be Skokie, but the problem is the ACLU. Having been the bastion of defense for demonstrators of unpopular causes and members of defiled minorities and parties for many years, the ACLU admittedly viewed its legal support of Nazis as a "cut and dried proposition." ${ }^{11}$ Of its 6,000 cases in 1977, only a few dealt with Nazis. It viewed the negative response of the membership to Skokie involvement as a function of poor communications. In its rundown of organizational interests-from sexual equality, racial justice, religious freedom, body control, constitutional rights of students, prisoners, mental patients, juveniles, the elderly, and the rights of privacy-there remained a gnawing feeling that rights had been sundered from obligations; and more cogently, even rights were considered selectively. For example, those sorts of Constitutional issues championed by conservatives, such as right to work legislation, seemed conspicuously absent on the ACLU list of priorities.

It would be a profound error to view the decline in membership of the ACLU, reputed to be 75,000 fewer than in 1974 (for a total of 200,000) as a direct consequence of the Skokie case. It represents a special sort of slander to claim that Jews, who continue to represent the backbone of ACLU branch

7i. D.B. Davis, The Fear of Conspiracy: Images of Un-American Subversion From the Revolution to the Present, at 279-80 (1971). 
action, are merely occasional friends of constitutional government who believe in Jewish interests first and foremost. What would be a more accurate assessment is that Jews tend to be more deeply concerned with the collective survival potentials of democratic society. They see this weakened resolve to struggle against the totalitarian temptation, whether in the United States or elsewhere, as an early warning signal of their own vulnerabilities. What is at stake therefore is not, as Aryeh Neier has claimed, defending "despised clients . . the Nazis today, Communists in the $1950 \mathrm{~s}$ " 72 but, more pointedly, a bad choice in orchestrating the public rights of Nazis over and against the private rights of the Jewish community. In this way, the righteous sense of ACLU support has turned into a myopia of ACLU self-righteousness; a failure to understand that it represents a self-interest group, as it should, but not necessarily American society, or for that matter American law, as a whole.

72. A. Neier, supra note 67 , at 32 . 


\section{.}

